Available online at: http://ejournal-balitbang.kkp.go.id/index.php/iaj

\title{
USE OF DIFFERENT PROBIOTICS FOR PREVENTION OF VIBRIOSIS DISEASE ON TIGER SHRIMP LARVAE REARED IN FIBERGLASS TANKS
}

\author{
Nurbaya” and Muharijadi Atmomarsono \\ Research Institute for Coastal Aquaculture and Fisheries Extension \\ Jl. Makmur Dg. Sitakka No. 129, Maros 90512, South Sulawesi \\ (Received 6 March 2018; Final revised 7 June 2018; Accepted 8 June 2018)
}

\begin{abstract}
To counter disease problems caused by vibriosis in shrimp hatchery, this recent study used three different probiotics to be tested on tiger shrimp (Penaeus monodon) postlarvae. The study arranged four treatments as follows: A: a combination of three liquid-form probiotics Brevibacillus laterosporus BT951, Bacillus subtilis $B M$ 12, and B. licheniformis BM 58; B: a combination of three powder-form probiotics Brevibacillus laterosporus BT951, Bacillus subtilis BM 12, and B. licheniformis BM58; C: a commercial powder probiotic containing Bacillus subtilis; and D: control (without probiotic), each treatment with three replications. This study was set up in a completely randomized design experiment using twelve fiberglass tanks filled with $750 \mathrm{~L}$ sterile sea water and stocked with 30,000 nauplii in the Awarange shrimp hatchery of the Research Institute for Brackishwater Aquaculture and Fisheries Extension Installation in Barru. Variables observed in this study were the survival rate of the shrimp postlarvae at the end of the experiment, total vibrio count (TBV) and total plate count of common bacteria (TPC) in the culture water. The results showed that the survival rate of tiger shrimp applied either in liquid (A: $61.5 \pm 4.7 \%$ or pow der form (B: $48.6 \pm 6.8 \%$, and control (without probiotic) (D: $51.2 \pm 4.4 \%$ were not significantly different $(P>0.05)$. However, survival rates in these three treatments differed $(\mathrm{P}<0.05)$ with that of the commercial probiotic $(C: 21.7 \pm 9.9 \%$. TBV/TPC ratio in the tank waters treated with the commercial probiotic $(2.26-37.52 \%$ was much higher than that of the liquid form probiotic (0.86-1.98\%, powder form probiotic (1.25-8.37\%), and control (1.93-2.84\%. Ammonianitrogen in treatment $C(1.462-2.989 \mathrm{mg} / \mathrm{L})$ was relatively higher than that of in treatment $A(1.595-2.435$ $\mathrm{mg} / \mathrm{L})$, treatment $B(1.644-2.115 \mathrm{mg} / \mathrm{L})$, and treatment D (1.051-1.858 $\mathrm{mg} / \mathrm{L})$.
\end{abstract}

\section{KEYWORDS: probiotic; survival rate; tiger shrimp postlarvae; vibriosis}

\section{INTRODUCTION}

Tiger shrimp (Penaeus monodon) aquaculture has suffered various shrimp diseases in both hatchery and grow-out systems, worldwide. Shrimp diseases caused by white spot syndrome virus, yellow head virus, and vibriosis occurred not only in tiger shrimp culture, but also in whiteleg shrimp culture (Lightner, 2011; Atmomarsono \& Susianingsih, 2013). The use of chemicals and antibiotics to cure shrimp diseases have been practiced in Thailand and Vietnam (Tran et al., 2017). Because of their negative impacts on human health, these chemical uses in aquaculture have now been banned in Indonesia. This has left fewer alternatives to combat or prevent these diseases oc-

\footnotetext{
\# Correspondence: Research Institute for Brackishwater Aquaculture and Fisheries Extension. Jl. Makmur Dg. Sitakka No. 129, Maros 90512, South Sulawesi, Indonesia Phone: + 62411371544

E-mail: nurbayaeka@ gmail.com
}

currence. One way to solve this problem is using probiotic to prevent shrimp diseases (Poernomo, 2004; Waston et al., 2008). The main culprit of shrimp diseases is vibriosis caused by Vibrio harveyi which could wipe out $100 \%$ of the cultured shrimp (Flegel, 2012; Atmomarsono \& Nurbaya, 2014). As an opportunistic pathogen, Vibrio harveyi will only become pathogenic bacteria causing shrimp diseases when the pond water quality is poor (Atmomarsono \& Susianingsih, 2015). This problem could be minimized by practicing the best aquaculture practices and applying proper probiotics. Probiotic bacteria are needed in the culture of larval aquatic organisms including black tiger shrimp to prevent bacterial diseases (Atmomarsono et al., 2009; Uddin et al., 2013).

Probiotic bacteria are non-pathogenic bacteria usually used to protect the shrimp from pathogenic microorganisms, inhibit the growth of pathogenic bacteria, neutralize poor pond water quality such as 
organic matter, $\mathrm{H}_{2} \mathrm{~S}, \mathrm{NH}_{3}-\mathrm{N}$, and $\mathrm{NO}_{2}-\mathrm{N}$, and function as food (Poernomo, 2004; Wang et al., 2008). Probiotic bacteria can be isolated from sea sediment, pond sediment, mangrove leaves, and macroalgae (Atmomarsono et al., 2009; Susianingsih et al., 2012; Tampangallo et al., 2013; Atmomarsono \& Nurbaya, 2014). There are various types of domestically produced and imported probiotics available in the market. Some of them are useful in the shrimp culture, but many of them are in effective.

The Research Institute for Brackishwater Aquaculture and Fisheries Extension develops and produces RICA (Research Institute for Coastal Aquaculture) probiotics originally isolated from the sea sediment, brackishwater pond, mangrove, and seaweed. RICA1 (Brevibacillus laterosporus BT951) is useful in controlling organic matter and $\mathrm{H}_{2} \mathrm{~S}$ in the ponds, while RICA-2 (Serratia marcescens MY1112) is beneficial for the shrimp growth and controlling ammonia-nitrogen (Atmomarsono et al., 2009). RICA-3 (Pseudoalteromonas sp. Edeep-1 BL542) has an important role in controlling nitrite and pathogenic Vibrio harveyi (Atmomarsono \& Susianingsih, 2013). RICA-4 (Bacillus subtilis BM 12) is useful in controlling organic matter and Vibrio harveyi in pond water. RICA-5 (Bacillus licheniformis BM58) is useful in controlling ammonia and nitrite in pond water (Tampangallo et al., 2013). A shrimp disease usually occurs when the accumulation of organic matter in the pond waters and sediments can not be controlled properly by the available natural bacteria. Since each RICA probiotic bacteria has a different role, the combination use of three different RICA probiotics might offer a full potential solution package to control organic wastes, ammonia-nitrogen, nitrite-nitrogen, and pathogenic Vibrio harveyi in shrimp ponds.

The aim of this study was to determine the best combination of probiotics in hatchery larval rearing of tiger shrimp using fiberglass tanks.

\section{MATERIALS AND METHODS}

This research was carried out in the shrimp hatchery of the Research Institute for Brackishwater Aqua-culture and Fisheries Extension Installation, Awarange, Barru Regency, South Sulawesi. A Completely Randomized Design (CRD) experiment with four treatments and three replications was used in this research. The four treatments applied were: A: a combination of three liquid-form probiotics RICA-1 (Brevibacillus laterosporus BT951), RICA-4 (Bacillus subtilis BM 12), and RICA-5 (Bacillus licheniformis BM 58); B: a combination of three powder-form probiotics RICA1 (Brevibacillus laterosporus BT951), RICA-4 (Bacillus subtilis BM 12), and RICA-5 (Bacillus licheniformis BM 58); $C$ : a commercial powder probiotic containing Bacillus subtilis; and D: control (without probiotic).

This research used twelve fiberglass tanks of one $\mathrm{m}^{3}$ in volume filled with $750 \mathrm{~L}$ of chlorinated-sterile sea water of about $30 \mathrm{ppt}$ and continuously aerated. Each tank was stocked with 30,000 nauplii (40 pcs/L), fed with Skeletonema sp. 15,000-75,000 cell/mL (started from the second day, just before Zoea-1 stage), commercial feed (started from Zoea-1 stage), and brineshrimp 10-20 nauplii Artemia/shrimp larvae (started from Mysis-3 stage or about day-9). Water exchange for about 5\%20\%was carried out daily after Mysis-3 stage. The probiotic applications for treatment $A$ and $B$ were as follows RICA-1 probiotic (Brevibacillus laterosporus BT951) was applied on day-3 (D-3), RICA-4 (Bacillus subtilis BM12) was applied on D-6, RICA-5 (Bacillus licheniformis BM 58) on D-9, and followed by RICA-1 applied daily from day-10 (PL-1) to day-21 (PL-12). For treatment $\mathrm{C}$, a commercial powder probiotic was applied on the same day and the same amount with treatment $B\left(1 \mathrm{~g} / \mathrm{m}^{3}\right)$. All of the applied probiotics in the shrimp culture water were estimated to reach about $10^{1} \mathrm{cfu} / \mathrm{mL}$ in population. To make this density, $100 \mathrm{~mL}$ probiotic in nutrient broth (liquid-form probiotic) was added to 900 $\mathrm{mL}$ sterile sea water and stirred for about 24-hours before used for the shrimp culture water in treatment A. To make powder-form probiotic (treatment B), $200 \mathrm{~mL}$ liquid-form probiotic was added to $400 \mathrm{~g}$ sterile cassava meal, then dried at $40^{\circ} \mathrm{C}$ in an oven for about 48-hours before used. The density of the applied bacteria in each treatment was checked before application.

Water salinity in the tank was maintained about $30 \mathrm{ppt}$, while water $\mathrm{pH}$ and temperature were monitored daily. The concentrations of total organic matter (TOM), ammonia-nitrogen $\left(\mathrm{NH}_{3}-\mathrm{N}\right)$, and nitritenitrogen $\left(\mathrm{NO}_{2}-\mathrm{N}\right)$ in the tank waters were monitored four times, namely at the stages of Zoea-1 (D-2), PL1 (D-10), PL-4 (D-13), and PL-10 (D-19). Using a modified spreading method (Buller, 2004), the total number of common bacteria (Total Plate Count $=$ TPC) in the tank water was measured in Tryptic Soy Agar (TSA), while the total number of Vibrio spp. (Total Bacteria of Vibrios= TBV) in the tank water was measured in Thiosulphate Citrate Bile Sucrose Agar (TCBSA). Both TBV and TPC were monitored in the same days with the water quality monitoring. The data on TBV and TPC were then analyzed descriptively. TBV/TPC ratios of the tank waters were also calculated based on the percentage of the number of TBV and TPC in each sample. When TBV/TPC ratio had increased more than 
$10 \%$ some pathogenic Vibrio spp. might be harmful to the shrimp (Atmomarsono \& Nurbaya, 2014). The survival rate and weight of tiger shrimp postlarvae in each tank were calculated after the shrimp reached postlarvae 12 (PL-12) and analyzed statistically to see if any differences among the treatments tested (Steel $\&$ Torrie, 1981).

\section{RESULTS AND DISCUSSION}

Table 1 shows that the average survival rate of tiger shrimp postlarvae (PL-12) in the tank water treated either liquid-form or powder-form RICA probiotics were significantly $(P<0.05)$ higher $(61.5$ $\pm 4.7 \%$ and $48.6 \pm 6.8 \%$ than that of the commercial probiotic powder $(21.7 \pm 9.9 \%$. However, there were no significant differences $(P>0.05)$ between the average survival rates of tiger shrimp postlarvae in the control $(51.2 \pm 4.4 \%$ and those of in treatment $A$ and $B$. These results showed that RICA probiotics either in liquid-form or in powder-form had better results than the commercial probiotic powder, but not better than the control (without probiotic). The shrimp mortality might be caused by the increasing number of vibrios and the increased level of ammonia-nitrogen concentration in the tank water.

RICA probiotics (treatment $A$ and $B$ ) contained three different bacteria, e.g.: Brevibacillus laterosporus BT951, Bacillus subtilis BM 12, and Bacillus licheniformis BM58, functioning together to control Vibrio spp., total organic matter, ammonia-nitrogen, and nitritenitrogen. Treatment $C$ (commercial probiotic) contained only Bacillus subtilis functioning in controlling Vibrio spp. and total organic matter. This was the reason why the concentration of ammonia-nitrogen $(1.462-2.989 \mathrm{mg} / \mathrm{L})$ and TBV/TPC ratio in treatment C $(2.26 \% 37.52 \%)$ were relatively higher than those in the liquid form probiotic (1.595-2.435 mg/L and $0.86 \%$ $1.98 \%$ respectively) and powder form probiotic (1.644$2.115 \mathrm{mg} / \mathrm{L}$ and $1.25 \% 8.37 \%$ respectively). However, RICA probiotics (treatment $A$ and $B$ ) and control (without probiotic) had not different significantly on the survival rates of the tiger shrimp postlarvae (Table $1)$. This might be caused by a low concentration of probiotic bacteria in the tank water (about $2.3 \times 10^{1}$ $\mathrm{cfu} / \mathrm{mL}$ ) at the initial stocking. This research advises that the probiotic bacteria should be applied at least ten times of the current application for future experiment or commercial applications.

The survival rates of tiger shrimp postlarvae resulted in this research were similar to those of Uddin et al. (2013) results, which were $52 \%$ for probiotictreated postlarvae and 35\%for untreated postlarvae. However, based on the individual survived postlarvae, the study findings (8-25 pcs/L) were relatively lower than that of Uddin et al. (2013) results (35-52 pcs/L). This difference might be caused by a higher ammonia-nitrogen concentration in the shrimp culture tank water in this research after PL-1 stage (2.30-5.08 mg/ L) (Table 2) compared to Uddin et al. (2013) results (0.9-2.5 mg/L).

It was previously reported by Atmomarsono et al. (2009) that RICA-1 probiotic consisting of Brevibacillus laterosporus BT951 could be used as an anti vibriosis, and was useful in demineralization of total organic matter. Tampangallo et al. (2013) also reported that RICA-4 (Bacillus subtilis BM 12) functioned as organic matter demineralizer, and RICA-5 (Bacillus licheniformis BM58) functioned as ammonia-nitrogen and nitritenitrogen controller in the culture media. Treatment C consisting of Bacillus subtilis could demineralize total organic matter, but not ammonia-nitrogen. This was the reason ammonia-nitrogen in treatment $C$ was relatively higher than those of the other treatments. This ammonia-nitrogen could be toxic for tiger shrimp postlarvae.

According to Chin \& Chen (1987) in Boyd (1990) 96-h LC50 and 24-h LC50 for tiger shrimp postlarvae were only about $1.26 \mathrm{mg} / \mathrm{L}$ and $5.71 \mathrm{mg} / \mathrm{L}$, respectively. This means that the concentration of ammonia-nitrogen in the culture media of this present research was relatively dangerous to tiger shrimp postlarvae. This might be the cause a direct or indirect shrimp mortality through the increase of TBV/ TPC ratio (percentage ratio of total bacteria of vibrios and total common bacteria) in the culture water during PL-4 stage in the control tank $(19.68 \%$ and during PL-10 stage in the commercial probiotic treated tank

Table 1. Survival rate and average weight of tiger shrimp postlarvae reared in fiberglass tank with different probiotics

\begin{tabular}{llcc}
\hline & \multicolumn{1}{c}{ Probiotics } & Survival rate (\%) & Postlarvae weight (mg/pcs) \\
\hline A. & Liquid-formed RICA & $61.5 \pm 4.7^{\mathrm{a}}$ & $1.7 \pm 0.2^{\mathrm{a}}$ \\
B. & Powder-formed RICA & $48.6 \pm 6.8^{\mathrm{a}}$ & $2.4 \pm 0.5^{\mathrm{a}}$ \\
C. & Commercial powder probiotic & $21.7 \pm 9.9^{\mathrm{b}}$ & $2.0 \pm 0.5^{\mathrm{a}}$ \\
D. & Control (without probiotic) & $51.2 \pm 4.4^{\mathrm{a}}$ & $1.3 \pm 0.6^{\mathrm{a}}$ \\
\hline
\end{tabular}


Usef different probiotics for prevention of vibriosis disease ..... (Nurbaya)

Table 2. Ranges of ammonia-nitrogen concentrations in tiger shrimp culture tank water at different larvae stages treated with different probiotics

\begin{tabular}{llcccc}
\hline & \multicolumn{1}{c}{ Probiotics } & $\begin{array}{c}\text { Zoea-1 } \\
\text { (mg/L) }\end{array}$ & $\begin{array}{c}\text { PL-1 } \\
\text { (mg/L) }\end{array}$ & $\begin{array}{c}\text { PL-4 } \\
\text { (mg/L) }\end{array}$ & $\begin{array}{c}\text { PL-10 } \\
\text { (mg/L) }\end{array}$ \\
\hline A. & Liquid-formed RICA & $0.076-0.217$ & $2.332-2.560$ & $4.520-5.083$ & $1.595-2.435$ \\
B. & Powder-formed RICA & $0.038-0.167$ & $2.477-2.660$ & $4.171-4.690$ & $1.644-2.115$ \\
C. & Commercial powder probiotic & $0.014-0.271$ & $2.392-2.535$ & $3.966-5.058$ & $1.462-2.989$ \\
D. & Control (without probiotic) & $0.039-0.074$ & $2.298-2.346$ & $4.231-4.835$ & $1.051-1.858$ \\
\hline
\end{tabular}

$(37.52 \%$. This finding was in line with the results reported by Atmomarsono \& Nurbaya (2014) and Susianingsih et al. (2017) where the increase of TBV/ TPC ratio in the culture water of more than $10 \%$ could be dangerous to the cultured shrimp.

Based on the individual weight size of the harvested postlarvae, postlarvae in treatment A (liquid-form RICA probiotic) were relatively more homogenous than that of the other treatments. However, the postlarvae in treatment $B$ (powder-form RICA probiotic) were relatively heavier $(2.4 \pm 0.5)$ than that of the other treatments. The smallest, lightest, and varying in weight of harvested tiger shrimp postlarvae were found in the control $(1.3 \pm 0.6)$ (Table 1). These results showed that all kinds of probiotics were needed to maintain the culture water clean, so that the cultured tiger shrimp could grow well homogenously. Besides that, without any addition probiotics, the natural bacteria were not enough to demineralize some of organic matter and ammonianitrogen. As a result, the ratio of total bacteria of vibrios and total common bacteria (TBV/TPC) in the control tank water during PL-4 stage had increased over $10 \%$

In general, vibrio numbers in the cultured shrimp water in this experiment were not significantly high (1-6,860 cfu/mL). According to Defoirdt (2007) Vibrio harveyi could be dangerous when its population in the cultured shrimp water reached $10^{4} \mathrm{cfu} / \mathrm{mL}$. However, eventhough the vibrio numbers in this research were still lower than $10^{4} \mathrm{cfu} / \mathrm{mL}$, they might cause shrimp mortality when TBV/TPC ratio increased over 10\%(Atmomarsono \& Nurbaya, 2014; Susianingsih et al., 2017).

Table 3 shows that nitrite-nitrogen concentrations in the tiger shrimp culture tank water tended to increase following the culture period. Fortunately, the highest concentration of nitrite-nitrogen in this research (1.843 $\mathrm{mg} / \mathrm{L})$ was still considered as a safe level for tiger shrimp postlarvae. According to Chen \& Chin (1988a) in Boyd (1990) the concentration of nitrite-nitrogen for tiger shrimp postlarvae should be less than $4.5 \mathrm{mg} / \mathrm{L}$. However, since ammonianitrogen concentration in the culture tank water was relatively high, it could cause the cultured shrimps to be more susceptible to pathogenic Vibrio harveyi especially when TBV/TPC ratio increased over $10 \%$ such as in treatments $C$ and $D$ (Table 5).

In general, a high concentration of ammonianitrogen followed by relatively low concentration of nitrite-nitrogen indicated that in the culture water might be not enough nitrification bacteria. In treatments $A$ and $B$, RICA- 4 and RICA-5 probiotics (Bacillus subtilis BM 12 and Bacillus licheniformis BM 58 respectively) could function as nitrification bacteria. Unfortunately, RICA-4 and RICA-5 probiotics were not used anymore in this research after tiger shrimp reached postlarvae one (PL-1). Instead of using RICA4 and RICA- 5 probiotics alternately, RICA-1 probiotic was used everyday from PL-1 to postlarvae 12 stage following the procedure used for the commercial probiotic application in treatment $\mathrm{C}$. It is suggested that for the future experiments, RICA-1, RICA-4, and RICA-5 probiotics should be used alternately to prevent the increase of total organic matter, ammonianitrogen, nitrite-nitrogen concentrations, and TBV/ TPC ratio in the shrimp culture water.

Based on Table 4, the ranges of total organic matter concentrations in the tiger shrimp culture tank water were quite high (29.4-64.4 mg/L). According to Madeali et al. (2009) the concentration of total organic matter in the shrimp culture water should be less than 30 $\mathrm{mg} / \mathrm{L}$, otherwise, the total organic matter could trigger the growth of pathogenic microorganisms that might be dangerous to the cultured shrimp.

Since total organic matter concentrations in the shrimp culture water were relatively high in all tanks, 
Table 3. Ranges of nitrite-nitrogen concentrations in tiger shrimp culture tank water at different larvae stages treated with different probiotics

\begin{tabular}{llcccc}
\hline \multicolumn{1}{c}{ Probiotics } & $\begin{array}{c}\text { Zoea-1 } \\
\mathbf{( m g / L )}\end{array}$ & $\begin{array}{c}\text { PL-1 } \\
\mathbf{( m g / L )}\end{array}$ & $\begin{array}{c}\text { PL-4 } \\
\mathbf{( m g / L )}\end{array}$ & $\begin{array}{c}\text { PL-10 } \\
\mathbf{( m g / L )}\end{array}$ \\
\hline A. & Liquid-formed RICA & $0.001-0.002$ & $0.014-0.043$ & $0.028-0.034$ & $1.385-1.843$ \\
B. & Powder-formed RICA & $0.007-0.033$ & $0.040-0.064$ & $0.053-0.188$ & $0.823-1.469$ \\
C. & Commercial powder probiotic & $0.007-0.024$ & $0.023-0.031$ & $0.033-0.042$ & $0.938-1.672$ \\
D. & Control (without probiotic) & $0.007-0.007$ & $0.042-0.054$ & $0.032-0.200$ & $0.360-1.686$ \\
\hline
\end{tabular}

Table 4. Ranges of total organic matter concentrations in tiger shrimp culture tank water at different larvae stages treated with different probiotics

\begin{tabular}{llcccc}
\hline & \multicolumn{1}{c}{ Probiotics } & $\begin{array}{c}\text { Zoea-1 } \\
\mathbf{( m g / L )}\end{array}$ & $\begin{array}{c}\text { PL-1 } \\
\mathbf{( m g / L )}\end{array}$ & $\begin{array}{c}\text { PL-4 } \\
\mathbf{( m g / L )}\end{array}$ & $\begin{array}{c}\text { PL-10 } \\
\mathbf{( m g / L )}\end{array}$ \\
\hline A. & Liquid-formed RICA & $29.4-52.6$ & $46.9-57.6$ & $45.7-60.1$ & $50.0-64.4$ \\
B. & Powder-formed RICA & $40.0-51.3$ & $50.0-63.8$ & $48.8-53.2$ & $41.9-57.6$ \\
C. & Commercial powder probiotic & $40.0-54.4$ & $50.0-61.3$ & $37.5-63.8$ & $43.2-53.8$ \\
D. & Control (without probiotic) & $46.9-50.7$ & $47.6-54.4$ & $42.5-52.6$ & $45.0-48.2$ \\
\hline
\end{tabular}

any kind of probiotic which could demineralize total organic matter was vitally important. The three treatments in this experiment had this kind of probiotic. Unfortunately, only RICA-1 probiotic (Brevibacillus laterosporus BT951) was used in treatments $A$ and $B$ after reaching PL-1. Bacillus subtilis is one of the commonly used probiotic bacteria in the commercial probiotic products. This could explain the high level of the general total organic matter concentration and the high concentration of ammonianitrogen. These two water quality parameters might trigger the growth of pathogenic vibrios, in TBV/TPC ratio over $10 \%$ in the control $(19.68 \%$ and treatment C (37.52\% (Table 5). This level of TBV/TPC ratios was relatively dangerous to shrimp (Atmomarsono \&
Nurbaya, 2014; Susianingsih et al., 2017). Madeali et al. (2009) similarly reported that the pathogenicity of Vibrio harveyi was enhanced by the high concentration of total organic matter (more than 30 $\mathrm{mg} / \mathrm{L}$ ) in the cultured shrimp water.

During the experiment, other water quality parameters in the treatment tanks were also monitored daily. Ranges of water quality parameters were as follows 30.0-32.4 ppt for water salinity, $30.0^{\circ} \mathrm{C}-32.2^{\circ} \mathrm{C}$ for water temperature, $7.88-8.22$ for water $\mathrm{pH}$, and $4.45-5.34 \mathrm{mg} / \mathrm{L}$ for dissolved oxygen. These water quality parameters were within the standard for the cultured tiger shrimp based on the study of Atmomarsono et al. (2009).

Table 5. Ranges of percentage of total bacteria of vibrios and total plate count ratio (TBV/TPC) in tiger shrimp culture tank water at different larvae stages treated with different probiotics

\begin{tabular}{llcccc}
\hline \multicolumn{1}{c}{ Probiotics } & $\begin{array}{c}\text { Zoea-1 } \\
(\mathbf{m g} / \mathbf{L})\end{array}$ & $\begin{array}{c}\text { PL-1 } \\
\mathbf{( m g / L )}\end{array}$ & $\begin{array}{c}\text { PL-4 } \\
(\mathbf{m g} / \mathbf{L})\end{array}$ & $\begin{array}{c}\text { PL-10 } \\
\mathbf{( m g / L )}\end{array}$ \\
\hline A. & Liquid-formed RICA & $0.20-0.40$ & $0.38-1.12$ & $0.31-1.96$ & $0.86-1.98$ \\
B. & Powder-formed RICA & $0.04-3.00$ & $0.51-7.85$ & $1.25-1.75$ & $1.25-8.37$ \\
C. & Commercial powder probiotic & $0.20-0.67$ & $0.92-8.03$ & $2.09-5.61$ & $2.26-37.52^{*}$ \\
D. & Control (without probiotic) & $0.03-0.33$ & $0.68-3.10$ & $\left.2.36-19.68^{*}\right)$ & $1.93-2.84$ \\
\hline
\end{tabular}

*) Bolded values mean lethal level for the cultured shrimp 


\section{CONCLUSION}

This current study concludes that in comparison with the control (without probiotic), the application of liquid-form or powder-form RICA probiotics could not increase $(P>0.05)$ survival rate of tiger shrimp postlarvae. Compared with commercial probiotic, the application of liquid-form or powder-form RICA probiotics had produced a better survival rate $(P<0.05)$ of tiger shrimp postlarvae. The survival rate of tiger shrimp postlarvae might be decreased by the high concentration of ammonia-nitrogen after PL-1 stage (2.30-5.08 mg/L) and the increase of TBV/TPC ratio after PL-4 stage (more than $10 \%$. This study suggests that the three different species of probiotic bacteria should be used alternately started from zoea1 until PL-12 at ten times concentration compared to the current research use to demineralize total organic matter, ammonia-nitrogen, and nitrite-nitrogen.

\section{ACKNOWLEDGEMENTS}

The authors would like to thank to all technicians and researchers of the Research Institute for Brackishwater Aquaculture and Fisheries Extension who provided help during the research experiment.

\section{REFERENCES}

Atmomarsono, M., Muliani, \& Nurbaya. (2009). Use of probiotic bacteria with different compositions to improve water quality and survival rate of tiger shrimp postlarvae. Jurnal Riset Akuakultur, 4(11), 73-83.

Atmomarsono, M. \& Nurbaya. (2014). Alternate use of different RICA probiotic bacteria on survival rate and production of cultured tiger shrimp in semi-intensive ponds. Indonesian Aquaculture Journal, 9(2), 155-164.

Atmomarsono, M. \& Susianingsih, E. (2013). Tiger shrimp culture in South Sulawesi, Indonesia using local probiotic bacteria. In Sudaryono, A., Hasan, M., \& Budi, G.P. (Eds.). Proceeding International Conference of Aquaculture Indonesia (ICAI) 2012. Indonesian Aquaculture Society. Semarang. p. 110-115.

Atmomarsono, M. \& Susianingsih, E. (2015). Effect of different probiotic bacteria on survival rate, growth, and production of whiteleg shrimp in traditional-plus technology. Indonesian Aquaculture Journal, 10(1), 71-79.

Boyd, C.E. (1990). Water quality in ponds for aquaculture. Birmingham, Alabama, USA: Birmingham Publishing Co., 482 pp.
Buller, N.B. (2004). Bacteria from fish and other aquatic animals: A practical identification manual. Wallingford, Oxfordshire, UK: CABI Publish, 361 $\mathrm{pp}$.

Defoirdt, T. (2007). Quorum sensing disruption and the use of short-chain fatty acids and polyhydroxy alkanoates to control luminescent vibriosis. PhD thesis. Belgium: Ghent University, 204 pp.

Flegel, T.W. (2012). Historic emergence, impact and current status of shrimp pathogens in Asia. J. Invertebr. Pathol., 110, 166-173.

Lightner, D.V. (2011). Virus diseases of farmed shrimp in the Western Hemisphere (the Americas): A review. J. Invertebr. Pathol., 106(1), 110-130.

Madeali, M.I., Atmomarsono, M., Muliani, \& Tompo, A. (2009). Effect of total organic matter concentrationon pathogenicity of Vibrio alginolyticus of tiger shrimp. $6 \mathrm{pp}$. In Djumanto, Dwiyitno, Chasanah, E., Heruwati, E.S., Irianto, H.E., Saksono, H., Yusuf, I.B.L., Basmal, J., Murniyati, Murwantoko, Probosunu, N., Rosmawaty, P., Rustadi, \& Ustadi (Eds.). Proceeding of the sixth National Seminar in Fisheries and Marine Research Results. Second Book: Fisheries Biotechnology. Gajah Mada University, Yogyakarta.

Poernomo, A. (2004). Technology of probiotics to solve the problems in shrimp pond culture and the culture environment. Paper presented in The National Symposium on Development and Scientific and Technology Innovation in Aquaculture, January 27-29, 2005, Patrajasa Hotel, Semarang, 25 pp.

Steel, R.G.D. \& Torrie, J.H. (1981). Principles and procedures of statistics. abiometrical approach $\left(2^{\text {nd }}\right.$ edition). International Student Edition. McGrawHill International Book Company, 633 pp.

Susianingsih, E., Kurniawan, K., \& Atmomarsono, M. (2017). Performance of cultured white-leg shrimp in RICA probiotic application in the ponds aerated with supercharge blower. Indonesian Aquaculture Journal, 12(1), 29-36.

Susianingsih, E., Nurbaya, \& Atmomarsono, M. (2012). Effect of different combinations of probiotic bacteria on survival rate and production of tiger shrimp in semi-intensive brackishwater pond. Jurnal Riset Akuakultur, 7(3), 489-502.

Tampangallo, B.R., Atmo marsono, M., \& Muliani. (2013). Isolation and identification of bacteria producing amylase, protease, chitinase, and cellulose enzymes isolated from macroalgae. Proceeding of Forum Inovasi Teknologi Akuakultur. Jakarta: Pusat Penelitian dan Pengembangan Perikanan Budidaya, p. 825-832. 
Tran, T.K.C., Clausen, J.H., Phan, T.V., Tersbol, B., \& Dalsgaard, A. (2017). Use practices of antimicrobials and other compounds by shrimp and fish farmers in Northen Vietnam. Aquaculture Reports, 7, 40-47.

Uddin, S.A., Kader, M.A., Sikder, M.N.A., Hakim, M.A., Alam, M.M., Azad, A. H., \& Hasan, C.K. (2013). Study of probiotics on the seed production of black tiger shrimp Penaeus monodon. Croation Journal of Fisheries, 71, 124-130.

Wang, Y.B., Li, J.R., \& Lin, J. (2008). Probiotics in aquaculture: Challenges and outlook. Aquaculture, 281, 1-4.

Waston, A.K., Kaspar, H., Lategan, M.J., \& Gibson, L. (2008). Probiotics in aquaculture: The need, principles and mechanisms of action and screening processes. Aquaculture, 274, 1-14. 